Article

\title{
Sustainable Wind Power Plant Modernization
}

\author{
Robert Kasner, Weronika Kruszelnicka *, Patrycja Bałdowska-Witos@, Józef Flizikowski and \\ Andrzej Tomporowski (D) \\ Department of Manufacturing Technology, Faculty of Mechanical Engineering, University of Science and \\ Technology in Bydgoszcz, 85-796 Bydgoszcz, Poland; robert.kasner@gmail.com (R.K.); \\ patrycja.baldowska-witos@utp.edu.pl (P.B.-W.); fliz@utp.edu.pl (J.F.); a.tomporowski@utp.edu.pl (A.T.) \\ * Correspondence: weronika.kruszelnicka@utp.edu.pl
}

Received: 29 February 2020; Accepted: 18 March 2020; Published: 20 March 2020

\begin{abstract}
The production of energy in wind power plants is regarded as ecologically clean because there being no direct emissions of harmful substances during the conversion of wind energy into electricity. The production and operation of wind power plant components make use of the significant potential of materials such as steel, plastics, concrete, oils, and greases. Energy is also used, which is a source of potential negative environmental impacts. Servicing a wind farm power plant during its operational years, which lasts most often 25 years, followed by its disassembly, involves energy expenditures as well as the recovery of post-construction material potential. There is little research in the world literature on models and methodologies addressing analyses of the environmental and energy aspects of wind turbine modernization, whether in reference to turbines within their respective lifecycles or to those which have already completed them. The paper presents an attempt to solve the problems of wind turbine modernization in terms of balancing energy and material potentials. The aim of sustainable modernization is to overhaul: assemblies, components, and elements of wind power plants to extend selected phases as well as the lifecycle thereof while maintaining a high quality of power and energy; high energy, environmental, and economic efficiency; and low harmfulness to operators, operational functions, the environment, and other technical systems. The aim of the study is to develop a methodology to assess the efficiency of energy and environmental costs incurred during the 25-year lifecycle of a $2 \mathrm{MW}$ wind power plant and of the very same power plant undergoing sustainable modernization to extend its lifecycle to 50 years. The analytical and research procedure conducted is a new model and methodological approach, one which is a valuable source of data for the sustainable lifecycle management of wind power plants in an economy focused on process efficiency and the sustainability of energy and material resources.
\end{abstract}

Keywords: wind power plant; efficiency; sustainable development; modernization; recycling

\section{Introduction}

The production of energy in wind power plants is regarded as ecologically clean because there being no direct emission of harmful substances during the conversion of wind energy into electricity [1,2]. Analyses of the environmental impact of wind power plants have mainly concerned their impact on birds, vibration emissions, noise-both audible and of the infrasound type-as well the impact on the surrounding landscape [3-5]. In a wider context, analyses have been conducted on the impact of wind farm lifecycles with the aid of the Life Cycle Assessment (LCA) method, including areas of potential impact on human health, the quality of the natural environment, and natural resources [6-9]. Analyses have also concerned the impact of the lifecycle of wind power plants on water and soil environment as well as their emissions into the atmosphere [10-12]. Many papers have also dealt with the aspects of the impact of particular elements and structural assemblies of wind power plants 
during their lifecycle, elements which include rotors, blades, towers, and various types of foundations, both offshore and onshore, with the result being that foundations and towers are the greatest source of potential negative impacts [1,13-17].

Less attention, however, has been given to the relationship between the benefits, costs, and efficiency in a given lifespan of a wind power plant [18]. Kasner [19] introduced the concept of the universal wind power plant integrated efficiency indicator which allows one to assess the efficiency of the use of inputs (costs) on the generation, use, and post-use management of the materials and components of a wind power plant in three areas: potential emissions, energy consumption, and financial costs to obtain benefits in the form of electricity production. Piasecka et al. [20], however, has proposed a method of assessing the destructiveness of costs appearing in the wind power plant lifecycle in four categories: de-ergonomicity, defunctionality, environmental performance breakdown, and biosphere conservation breakdown, showing that the greatest negative impact of both onshore and offshore wind power plants occur in the area of de-ergonomicity. Much research has examined the benefits resulting from the operation of wind power plants, i.e., electricity production, or the ways to both predict or increase wind farm productivity [21-26]. Economic matters relating to the operation of wind power plants have also been addressed as one important aspect thereof [27-30].

The significant potential of construction materials such as steel, plastics, and concrete are used to produce wind power plant components. Energy costs must also be incurred in both the production and operation thereof [1]. In the process of decommissioning wind power plant units, both their material and energy potential must be utilized by means of landfilling or recycling. With regard to the material stages of the lifecycle, production, operation with servicing and power supply, and the post-use utilization of the wind power plant are significant in a complete environmental impact assessment [31-33].

Europe has launched international efforts to protect the environment in the adopted provisions of, inter alia, the Kyoto Protocol on climate change and the focus of European Union (EU) policy on sustainable development and low-carbon economies [34]. The concept of sustainable economic development requires that one take into account the environmental, energy, economic, and social aspects of the lifecycles of technical facilities as well as changes in the management of their lifecycles [35-39], e.g., by modernizing wind power plants and extending their lifecycles [40-42] (Figure 1).

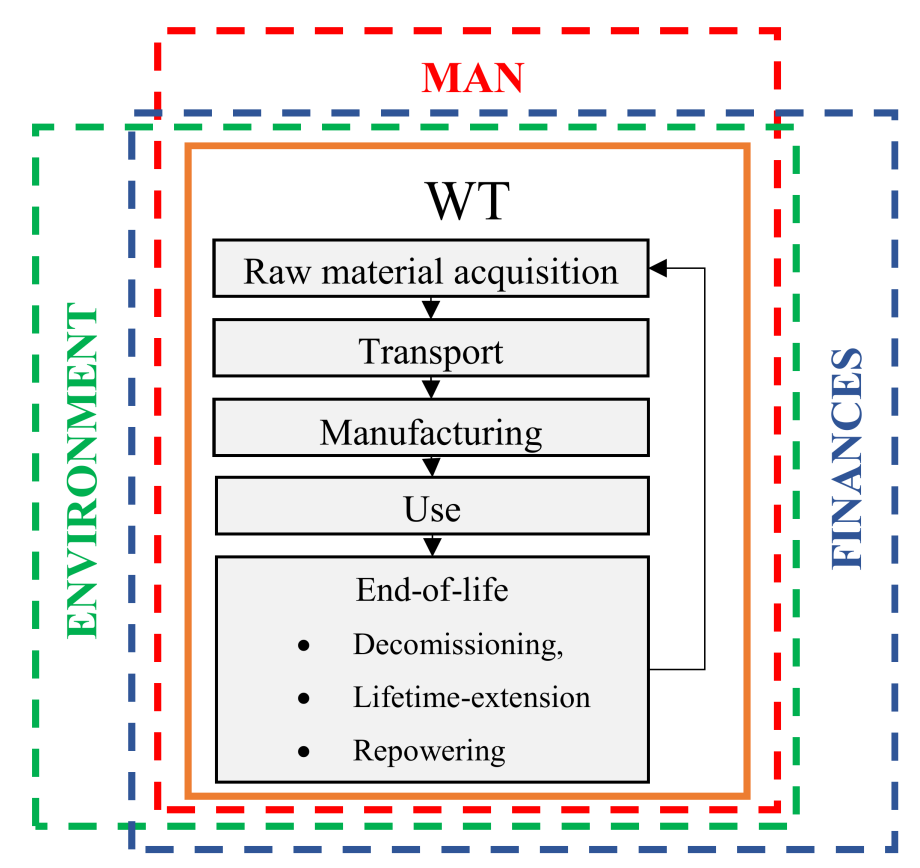

Figure 1. Spaces in sustainable lifecycle management, WT-wind turbine. 
The lifespan of wind power plants is accepted to be 25 years and, in most cases, they are disassembled after 25 years [20,43-46]. Many components, including structural elements, can continue to operate for the next 25 years, while the wind power plant itself can operate much longer after the replacement of some components and elements with new ones, which will further reduce the harmful environmental impact of energy production in wind power plants $[40,46]$. There are basically three distinct strategies for dealing with the wind turbines at the end of their lifecycles: decommissioning, lifetime-extension, and repowering. The aim of decommissioning is to disassemble the wind power plant after it has reached the end of its lifecycle and to then recycle them $[41,42,47,48]$. Lifetime-extension, in turn, includes measures to extend the wind power plant's lifecycle by replacing worn out elements with new ones. This therefore includes the modernization of mechanical parts and control systems (Table S1 in Supplementary Materials) [40]. The idea behind repowering is to erect a new wind power plant with greater power production capacity at the site of the old one which has ended its lifecycle [40].

The modernization of wind power plants, the replacement of their parts with new ones, and the extension of their lifecycle all fall in line with the aim of sustainable development, and in particular, with the implementation of the slogan: "A resource-efficient Europe." Changes in wind power plant lifecycle management are primarily meant to be harmless, efficient, and of high-quality. Efforts to undertake sustainable modernization make it possible to:

- Reduce both emissions (e.g., carbon dioxide) and natural resource use and energy use per unit of electricity produced;

- Reduce the intensity of resource use when constructing wind power plants;

- Increase energy security by extending the lifecycle and availability of wind power plants.

In the world literature one usually finds analyses concerning mainly the assessment of wind power plant profitability and productivity after lifetime-extension and repowering $[41,42,47,48]$, yet what is missing is a comprehensive assessment of the benefits as well as the ecological, energy, and economic costs arising from modernizations in wind power plant lifecycles. Ziegler et al. [41] performed analysis of the technical, economic, and legal possibilities relating to lifetime-extension showing that the profitability of these processes depend on energy market prices and thus differ depending on the country. Piel et al. [42] proposed a decision-support system for wind power plant operators on how to end the facility's lifecycle, taking into account land topography, wind resources, turbine type, and financial data in the profitability assessment of the processes of decommissioning, repowering, and lifetime extension. A methodology was also developed to assess the possibilities of extending the lifetime of wind turbine towers with special consideration given to wind and stress variables occurring in this structural element [49]. Martinez et al. [50] have shown that the repowering process causes an increase in the wind turbine's production of electricity at the same site with a smaller environmental impact. Studies concerning repowering have shown that such efforts give rise to an increase in both power and productivity [48]. There are no studies on the impact that standard replacements and modernizing replacements have (serving to extend wind power plant lifetime) on integrated efficiency. Therefore, it is worth considering the hypothesis as to whether the benefits and costs of operating a wind power plant after modernization, e.g., in a 50-year operation period, are as effective as in a 25-year lifecycle.

In light of the above, the aim of this paper is to develop a methodology to assess the efficiency of energy and environmental costs incurred in the lifecycle processes of a $2 \mathrm{MW}$ wind power plant in a 25-year use-period and to assess the very same power plant after it has been subject to sustainable modernization to extend its lifecycle to 50 years. The analytical and research procedure conducted is a new model and methodological approach, one which is a valuable source of data for the sustainable lifecycle management of wind power plants in an economy focused on process efficiency and the sustainability of energy and material resources. 


\section{Materials and Methods}

\subsection{The Integrated Efficiency of Sustainable Modernization}

Efficiency of operation is a goal, a state of energetics that makes it possible to estimate, optimize, modernize, and innovate ideas, constructions, and processes by comparing benefits, costs, and their relation in a given lifecycle. It means effectively using incurred costs to obtain benefits or expected results $[19,51,52]$.

Efficiency in systems engineering is treated as a system feature, one that is measurable, useful for comparing systems of a given class, which expresses different aspects of performance in different time intervals and can be expressed differently depending on the class of the systems, their purpose, and conditions $[19,51,53]$.

The assessment of modernization efficiency herein was based on mathematical models which allow for the analyses and assessments consisting of a comparison of benefits and costs in a lifecycle.

To assess the operation of a wind power plant's lifecycle, an integrated efficiency indicator was defined [19], which can describe efficiency in the environmental, economic, and energy spheres depending on the reference point that is established [19]

$$
E(t)=\frac{U(t)}{N(t)}
$$

where:

$E(t)$ - the integrated efficiency indicator in the lifecycle,

$U(t)$ - the benefits in the lifecycle (environmental, energy, and economic),

$N(t)$ - costs in the lifecycle (environmental, energetic, economic),

$t$-time of use.

The size of $U(t)$ and $N(t)$ indicate the values of the benefits obtained (the effects) and the costs incurred up to time $t$ from the beginning of operation $(t=0)$.

Benefits from the operation of a wind power plant $U(t)$ include, inter alia, a product in the form of energy, financial revenue, improvement in quality, reductions of emissions into the environment, the diversification of energy sources, the development and activation of the surroundings, as well as other potential benefits which as of today cannot be defined.

In a given period, the function $U(t)$ can take the form of both positive and negative values [19],

$$
u(t)=\frac{d U(t)}{d t}
$$

while the value of function $U(t)$, on the basis of the elementary values $u(t)$, depending on whether they are continuous functions or discrete ones, can be determined from the following dependencies [19]

$$
\begin{aligned}
U(\tau) & =\int_{0}^{\tau} u(t) d t \\
U(\tau) & =\sum_{i}^{l} u_{i} \cdot \Delta t_{i}
\end{aligned}
$$

Operation costs $N(t)$ are to be understood as: negative impacts on the environment, energy use in the entire lifecycle, financial costs incurred, negative societal costs, and potential costs which are currently unknown.

The function $N(t)$ in the time interval $(0, t)$ is a non-diminishing time function, that is, in each of the elementary intervals ( $\Delta t$ or $\mathrm{dt} /$ ) the elementary value of costs is not less than zero [19]

$$
n(t)=\frac{d N(t)}{d t}
$$


while the value of function $N(t)$, depending on whether the function $n(t)$ is continuous or discrete, can be determined from the dependency [19]

$$
\begin{aligned}
& N(\tau)=\int_{0}^{\tau} n(t) d t \\
& N(\tau)=\sum_{i}^{T} n_{i} \cdot \Delta t_{i}
\end{aligned}
$$

The cost can be expressed with various elements in various units.

For a wind turbine undergoing modernization during its use, the integrated efficiency indicator is defined by a system of equations (Figure 2)

$$
E(t)= \begin{cases}\frac{U_{r} \cdot t}{N_{W}^{1}+N_{r} \cdot t+N_{Z}^{1}} \cdot \frac{U_{r} \cdot t}{\frac{\left.N_{W}^{1}+N_{W}^{2}\right)+N_{r} \cdot t+\left(N_{Z}^{1}+N_{Z}^{2}\right)}{U_{r} \cdot t}} & \text { dla } 0 \leq t \leq t_{L C 1} \\ \frac{\left.U_{W}^{1}+N_{W}^{2}+N_{W}^{3}\right)+N_{r} \cdot t+\left(N_{Z}^{1}+N_{Z}^{2}+N_{W}^{3}\right)}{\left(N_{W}^{1}\right.} & \text { dla } t_{L C 2}<t \leq t_{L C 3} \\ \vdots & \text { dla } t_{L C(n)}<t \leq t_{L C(n+1)} \\ \frac{U_{r} \cdot t}{\sum_{i=1}^{n+1} N_{W}^{i}+N_{r} \cdot t+\sum_{i=1}^{n+1} N_{Z}^{i}} & \end{cases}
$$

where: $U_{r}$ average annual productivity, $t$ - time counted from the beginning of the use-stage, $n-$ number of use-stages throughout the lifecycle, $t_{L C n}$ - the end of the subsequent use-stage, $N_{W^{\prime}}^{1} N_{W^{\prime}}^{2}$ $N_{W}^{3}, N_{W}^{n}$ - costs at the production-stage of elements in the first, second, third $n$ - nth stages, respectively, $N_{r}$ - average annual costs at each stage of use, $N_{Z}^{1}, N_{Z}^{2}, N_{Z}^{3}, N_{Z}^{n}$ - costs at the post-use management stage of elements utilized in the first, second, third, $n$-nth use-stages, respectively.

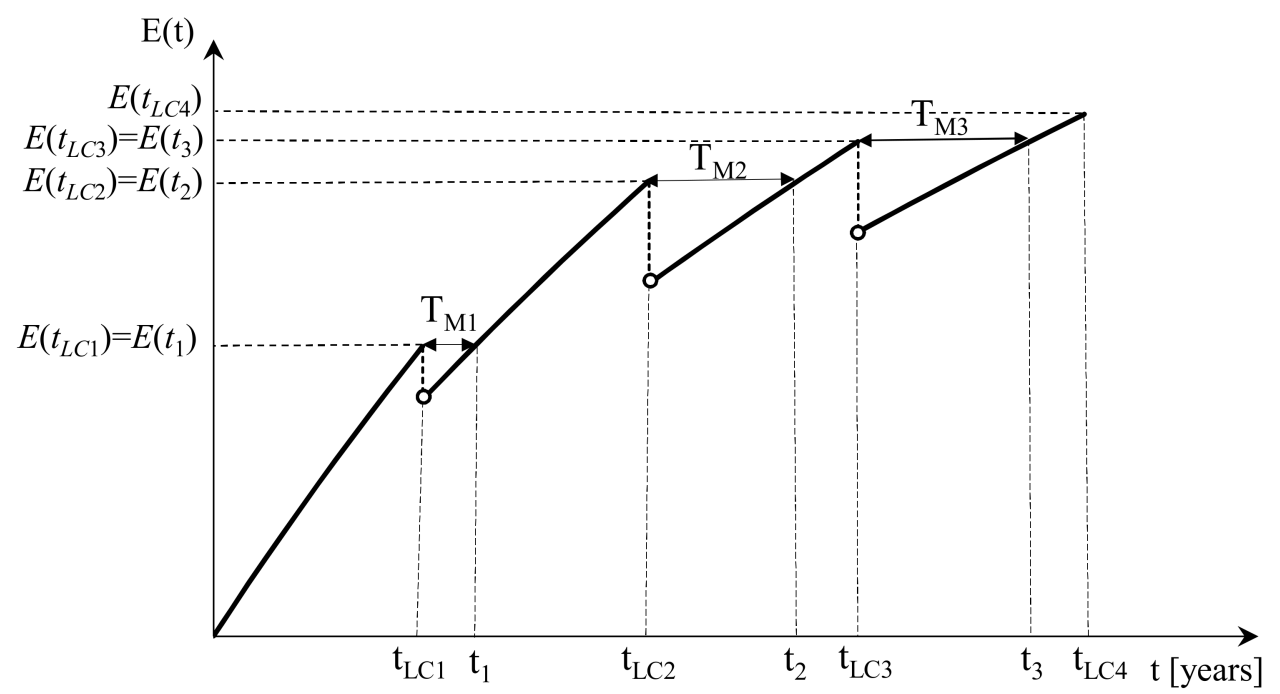

Figure 2. A graphical interpretation of the integrated efficiency indicator in the lifecycle (dependency (7)), including the sustainable modernization indicator (dependence (20)) and the time of the return on costs for modernization (dependence (18)).

The model proposed herein can be applied to assess the efficiency of existing wind power plants as well as those being designed to compare the effects of their operation after the modernization and extension of their lifecycle. 
Sustainable modernization, which in essence refers to the process of replacing structural components with new or modernized ones, is a process that encompasses multiple aspects, all of which serve the goal of erecting a wind power plant with the use-properties of a new one. This process includes the use of wind power plant materials and resources, and additionally, its executive and energy resources after completion of the use-stage.

\subsection{Payback Time for Moderinzation Costs}

The first indicator of the assessment of sustainable modernization is time $T_{M n}$ after which there is a return to the pre-modernization efficiency of the use of costs (Figure 2). The payback time for modernization costs is defined as

$$
T_{M n}=t_{n}-t_{L C n}
$$

where:

$t_{n}$ - the time after which post-modernization efficiency is equal to pre-modernization efficiency, counted from the beginning of use,

$t_{L C n}$ - the end of a subsequent use-stage

Time $T_{M n}$, after which pre-modernization efficiency is achieved, is essentially unknown, but determinable. If one condition is met (Figure 2)

$$
E\left(t_{n}\right)=E\left(t_{L C n}\right), \quad \text { gdzie } t_{n} \neq t_{L C n}
$$

then after modernization at time $t_{n}$ one achieves the efficiency of the source of energy which is the moment modernization work was begun at time $t_{L C n}$. The result is the equation

$$
\frac{U_{r} \cdot t_{n}}{\sum_{i=1}^{n+1} N_{W}^{i}+N_{r} \cdot t_{n}+\sum_{i=1}^{n+1} N_{Z}^{i}}=\frac{U_{r} \cdot t_{L C n}}{\sum_{i=1}^{n} N_{W}^{i}+N_{r} \cdot t_{L C n}+\sum_{i=1}^{n} N_{Z}^{i}}
$$

After transformations one obtains

$$
\begin{gathered}
t_{n}\left(\sum_{i=1}^{n} N_{W}^{i}+N_{r} \cdot t_{L C n}+\sum_{i=1}^{n} N_{Z}^{i}\right)=t_{L C n}\left(\sum_{i=1}^{n+1} N_{W}^{i}+N_{r} \cdot t_{n}+\sum_{i=1}^{n+1} N_{Z}^{i}\right) \\
t_{n} \cdot \sum_{i=1}^{n} N_{W}^{i}+t_{n} \cdot t_{L C n} \cdot N_{r}+t_{n} \cdot \sum_{i=1}^{n} N_{Z}^{i}-t_{L C n} \cdot \sum_{i=1}^{n+1} N_{W}^{i}-t_{n} \cdot t_{L C n} \cdot N_{r}-t_{L C n} \cdot \sum_{i=1}^{n+1} N_{Z}^{i}=0 \\
t_{n} \cdot \sum_{i=1}^{n} N_{W}^{i}+t_{n} \cdot \sum_{i=1}^{n} N_{Z}^{i}-t_{L C n} \cdot\left(N_{W}^{n+1}+\sum_{i=1}^{n} N_{W}^{i}\right)-t_{L C n} \cdot\left(N_{Z}^{n+1}+\sum_{i=1}^{n} N_{Z}^{i}\right)=0 \\
t_{n} \cdot \sum_{i=1}^{n} N_{W}^{i}+t_{n} \cdot \sum_{i=1}^{n} N_{Z}^{i}-t_{L C n} \cdot N_{W}^{n+1}-t_{L C n} \cdot \sum_{i=1}^{n} N_{W}^{i}-t_{L C n} \cdot N_{Z}^{n+1}-t_{L C n} \cdot \sum_{i=1}^{n} N_{Z}^{i}=0 \\
\left(t_{n}-t_{L C n}\right) \cdot \sum_{i=1}^{n} N_{W}^{i}+\left(t_{n}-t_{L C n}\right) \cdot \sum_{i=1}^{n} N_{Z}^{i}=t_{L C n} \cdot N_{W}^{n+1}+t_{L C n} \cdot N_{Z}^{n+1} \\
\left(t_{n}-t_{L C n}\right) \cdot\left(\sum_{i=1}^{n} N_{W}^{i}+\sum_{i=1}^{n} N_{Z}^{i}\right)=t_{L C n}\left(N_{W}^{n+1}+N_{Z}^{n+1}\right) \\
t_{n}-t_{L C n}=\frac{t_{L C n}\left(N_{W}^{n+1}+N_{Z}^{n+1}\right)}{\sum_{i=1}^{n} N_{W}^{i}+\sum_{i=1}^{n} N_{Z}^{i}}=\frac{t_{L C n}\left(N_{W}^{n+1}+N_{Z}^{n+1}\right)}{\sum_{i=1}^{n}\left(N_{W}^{i}+N_{Z}^{i}\right)}
\end{gathered}
$$


Because $T_{M n}=t_{n}-t_{L C n}$, the dependency of the payback time on pre-modernization efficiency is expressed as follows:

$$
T_{M n}=\frac{t_{L C n}\left(N_{W}^{n+1}+N_{Z}^{n+1}\right)}{\sum_{i=1}^{n}\left(N_{W}^{i}+N_{Z}^{i}\right)}
$$

\subsection{The Sustainable Modernization Indicator}

The second indicator of sustainable modernization assessment is the indicator of sustainable modernization $E_{M}$, which expresses the relation of the integrated efficiency indicator after the completion of the use-stage after modernization $E\left(t_{L C(n+1)}\right)$ is performed to the integrated efficiency indicator before the beginning of modernization $E\left(t_{L C n}\right)$ (Figure 2)

$$
\begin{gathered}
E_{M n}=\frac{E\left(t_{L C(n+1)}\right)}{E\left(t_{L C n}\right)} \\
E_{M n}=\frac{\frac{t_{L C(n+1)} \cdot U_{r}}{\sum_{i=1}^{n+1} N_{W}^{i} \sum_{i=1}^{n+1} N_{Z}^{i}+t_{L C(n+1)} \cdot N_{r}}}{\frac{t_{L C n} \cdot U_{r}}{\sum_{i=1}^{n} N_{W}^{i}+\sum_{i=1}^{n} N_{Z}^{i}+t_{L C n} \cdot N_{r}}}=\frac{t_{L C(n+1)}\left[\sum_{i=1}^{n}\left(N_{W}^{i}+N_{Z}^{i}\right)-t_{L C n} \cdot N_{r}\right]}{t_{L C n}\left[\sum_{i=1}^{n+1}\left(N_{W}^{i}+N_{Z}^{i}\right)-t_{L C(n+1)} \cdot N_{r}\right]}
\end{gathered}
$$

where $E_{M n}$ is the efficiency of subsequent modernizations

Figure 2 presents the dependence of integrated efficiency as a function of the time of use. Integrated efficiency as a function of time is a non-decreasing function. Its increase at the use-stage results from the benefits that grow in time that are generated at this stage. In the wind power plant's lifecycle, an increase in the benefits of its operation is observed (an increase in the electricity produced), with a constant value of both the costs to produce elements and costs relating to post-use management, and a slight increase in costs at the use-stage (maintenance, repairs, energy consumption). The increase in costs at the use-stage is much smaller than the increase in benefits at the same time. Considering the fact that the efficiency indicator is a ratio of benefits to costs, with the assumptions above, said indicator will be an increasing function. At the time of modernization $\left(t_{L C n}\right)$, a reduction in integrated efficiency results from the calculation of the costs to manufacture the replaced elements and to undertake their post-use management during modernization, which increases the value of costs throughout the lifecycle.

\subsection{Methodology for Determining the Benefits and Costs in a Wind Power Plant's Lifecycle}

A Vestas V90/105 m wind power plant with a nominal electrical capacity of 2 MW located in central Poland was analyzed in detail. Table 1 presents the basic data of the wind power plant analyzed with the LCA method.

Table 1. Basic data of the Vestas V90 wind turbine.

\begin{tabular}{lll}
\hline Description & Unit & Quantity \\
\hline Lifetime & years & 25 \\
Rating per turbine & MW & 2 \\
Generator type & - & Three-phase asynchronous generator \\
Hub height & $\mathrm{m}$ & 105 \\
Rotor diameter & $\mathrm{m}$ & 90 \\
Tower type & - & Standard steel \\
Production & MWh per year & 5325 \\
Plan location & - & Poland \\
\hline
\end{tabular}


The Vestas V90 three-blade rotor with a $90 \mathrm{~m}$ diameter and the nacelle housing the main shaft, generator, transformer, gearboxes, and brakes are located atop a 105 meter tower. The Vesta V90 wind turbine is an upwind turbine with an adjustable blade pitch system featuring active directionality. The turbine is equipped with a $2.0 \mathrm{MW}$ power-rated generator. It uses a OptiTip $囚$ microprocessing system for blade pitch control as well as the OptiSpeedTM function (for speed regulation). Owing to these functions, the wind turbine rotor can work at variable rotational speeds, helping to keep power output at or close to the rated power (data from the producer) [54].

The V90 turbine is equipped with a rotor possessing a diameter of $90 \mathrm{~m}$ which consists of three blades and a hub. The $44 \mathrm{~m}$ blades, laminated with the use of a "prepreg" type material (PP), are constructed from carbon fiber and fiberglass. The blades consist of two panels attached to a support beam (data from the producer) [54].

Wind energy transferred to the turbine is corrected by adjusting the blade pitch, depending on the control strategy that has been adopted. The blades connect to the hub by means of double row, four-point contact ball bearings. The hub is used to seat the three blades and transmit the forces of action to the main bearing. The hub design supports the blade bearings and the cylinder that regulates the blade angle. The main gearbox transmits torque from the rotor to the generator. It consists of a planetary gearbox connected to a two-stage parallel gearbox, reaction rods, and vibration dampers. The torque is transferred from the high-speed shaft to the generator via a composite clutch behind the disc brake. The generator bearings are lubricated and the grease is fed continuously by an automatic lubricator. The grease flow is approximately $2400 \mathrm{~cm}^{3}$ per year. The high-speed shaft coupling transmits torque from the high-speed output shaft of the gearbox to the input shaft of the generator. It consists of two composite discs, an intermediate sleeve with two aluminum flanges and a fiberglass sleeve. The nacelle housing is made of glass-fiber-reinforced polymers. The nacelle base plate consists of two parts: the front one, made of cast iron, and the back one in the form of a girder construction. A three-phase asynchronous generator with a coiled rotor is connected to the Vestas Converter System (VCS, Vestas Converter System) via a slip ring system (data from the producer) [54].

The Vestas V90 tubular towers have internal flange connections. The tower is erected on a reinforced concrete foundation with an embedded starter ring. The tower is connected to the ring by means of bilateral flanges (internal and external). The list of materials that form the Vestas V90 2 MW wind power plant is presented in Table S2 (in Supplementary Materials).

A comparative analysis of the efficiency of the aforementioned wind power plant in a 25-year operation period [43-46] was performed and the same was done for the same turbine modernized in a 50-year lifecycle. The analysis is primarily intended to describe the existing reality, but also to help model future changes to define recommendations to develop more pro-environmental solutions.

The wind power plant examined herein is a technically mature construction. As part of a service package, the producer guarantees its constant time-availability and productivity throughout the entire 25-year use-period. The periods of reduced reliability at the beginning and end of the use-period of this wind power plant as well as the decreasing operational efficiency throughout its use-period $[55,56]$ are negligible and do not affect the efficiency assessments of the costs incurred.

The energy benefits $U(t)$ are the sum of the average annual values of energy production in the wind power plant $U_{\mathrm{r}}$ over an assumed lifetime $t_{L C 1}$ of 25 years [43-46]. The annual environmental and energy benefits $U_{r}$ are defined as the average annual long-term productivity determined on the basis of data from three years of production (2013-2015) and long-term data that takes into account the 25-year reference period. These benefits came to $5325 \mathrm{MWh} /$ year for the power plant tested [19].

The costs for the 25-year period of use were determined as the sum of costs at individual stages of the wind power plant lifecycle, i.e., costs to generate $N_{W^{\prime}}^{1}$, the average annual costs for operation $N_{r}$, and the post-use management $N_{Z}^{1}$ in the form of landfilling and recycling. For costs on post-use management, it was assumed that $90 \%$ of materials are recycled and $10 \%$ are landfilled, which results from the current possibilities of material processing and available reports on wind power plant recycling [57]. 
The study took into consideration the management of post-use materials and elements of the wind power plant, which included $90 \%$ recycling and 10\% landfilling of the waste for materials that could not be reused or processed. As a complex mechanical structure, a wind power plant is built of many different materials, including steel, polymer materials, carbon fibers, fiberglass, copper, iron, and rubber materials, which are subject to various recycling methods to varying degrees, including mechanical recycling and reuse, material recovery, incineration with energy recovery, and pyrolysis [58]. The data presented by the wind power plant manufacturers [59-63] indicate that it is technically feasible to recycle $90 \%$ of its materials and to transfer $10 \%$ of its materials to landfills. This data correspond to the actual conditions. Some of the materials of the blades, nacelle and rotor housing require a specialized method of energy recycling (incineration with energy recovery, pyrolysis), during which waste intended for the landfill is produced. The analysis in this paper covered the entire lifecycle of the wind power plant, including post-use management; therefore, to calculate the result of the wind power plant's total environmental impact, it is important to take into account the management methods, as-depending on the level of recycling and landfilling-results will vary. This paper took into account data concerning the recyclability of components corresponding to the actual technical possibilities thereof.

\subsubsection{Determining Costs with the Aid of the LCA Method}

The LCA method was used to determine energy and environmental costs in the lifecycle, a method which is a technique from process management that allows for the assessment of potential environmental threats triggered by proesses arising in the lifecycle of a given technical object. Analysis was conducted in accordance with ISO norm 14044 [64].

Aim and scope of the analysis

The purpose of analyzing environmental impacts is to identify potential negative environmental impacts occurring at particular material stages of the lifecycle, assuming a 25-year wind power plant lifecycle and a 50-year lifecycle for the modernized power plant where the nacelle and rotor have been replaced to determine the values of the integrated efficiency indicators in the context of environmental and energy costs, as well as the time of return on modernization and the sustainable modernization indicator. Environmental impact was determined using the Eco-indicator 99 model using SimaPro software. The Eco-indicator 99 method belongs to a group of methods modelling environmental impact at the level of endpoints of an environmental mechanism. The characterization process takes place for eleven impact categories, falling within three larger groups defined as impact areas or damage categories [65-67]. The following impact areas have been distinguished: human health, ecosystem quality, and raw material resources [68]. The results of the third stage of environmental analysis, i.e., grouping and weighing, were used to determine the environmental costs. Environmental coefficients are the result of this stage, and they are expressed in $\mathrm{Pt}$ (environmental points), which are aggregated units that make it possible to compare the results of the ecobalances herein $[69,70]$. One thousand environmental points are equal to the environmental impact of an average European during a year $[65,71]$. The cut-off point was equal to $0.05 \%$. The analysis included eleven impact categories, yet in order to determine environmental costs, only the total impact of the wind power plant's lifecycle at particular stages of the lifecycle, i.e., production, use, and post-use development, was taken into account. The analysis also took into account the values of emissions of substances causing acidification $\mathrm{SO}_{2} \mathrm{eq}$ (in $\mathrm{kg}$ ) and emissions of substances causing eutrophication $\mathrm{PO}_{4} \mathrm{eq}$ (in $\mathrm{kg}$ ), which were treated as environmental costs in the determination of sustainable modernization assessment models. The procedure of determining environmental impacts consisted of four stages: defining the aim and scope of the analysis, analysis of the collection of inputs and outputs, LCAI analysis, and interpretation of the results [72,73].

The cumulative energy demand method (CED) makes it possible to define the cumulative energy demand (expressed in GJ) for particular stages of the lifecycle [74,75]. The reults of the CED analysis were the input value for determining the value of the integrated efficiency index from energy costs, 
from the time of the return on energy costs for modernization, and from the modernization indicator in relation to energy costs.

The Intergovernmental Panel on Climate Change, Global Warming Potential method (IPCC) was used to determine the amount of greenhouse gas emissions in certain stages of the material lifecycle of the wind power plant $[76,77]$. This gave the value of $\mathrm{CO}_{2}$ eq emissions (in kilograms), which was used to determine the value of integrated efficiency (Equation 7).

System limit and the functional unit

The borders of Poland were assumed as a territorial limitation. The function of the object was the production of electricity. The productivity of the wind power plant in a 25 -year period of use was taken as the functional unit.

The analysis assumed a 25-year wind power plant lifecycle [43-46] and a 50-year lifecycle of the same wind power plant which was subject to modernization. The scope of the modernization included the replacement of the nacelle and rotor along with the blades after a 25-year period of use. Three material stages of the lifecycle were examined: production, use, and post-use management in the form of recycling (90\%) and landfilling (10\%) [57]. Excluded from the system were the stages of transportation, of sale, of technical tests and storage because of a lack of proper data and the impact differences in the means of transport, which to a large degree are dependent on the location of the object. In the Figure 3 the scope of LCA analysis is presented.

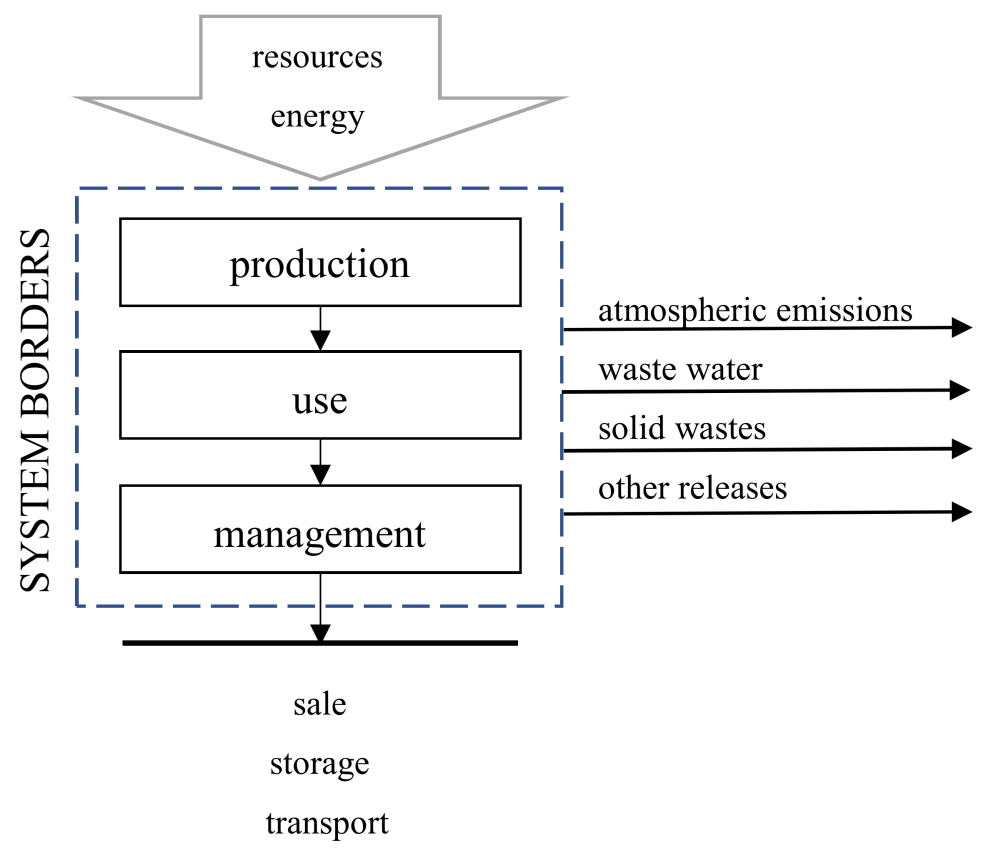

Figure 3. Scope of the LCA analysis of the turbine in a 25-year lifecycle and the same turbine after modernization.

\section{Analysis of the collection of inputs and outputs, data aggregation and validation}

Data were collected and divided into particular processes and unit elements with the identification of their inputs and outputs. Process inputs are primarily comprised of materials, natural resources, and energy while outputs are comprised of waste and emissions. The data correspond to one wind power plant. The input data concerned materials and elements of the wind power plant acquired from materials of the producer and from the authors' own research. Data concerning productivity come from a 3 years period $(2013-2015)$ of the wind power plant's operation. Less essential data concerning materials and processes were taken from SimaPro databases. In order to create an inventory table, individual environmental impacts of the same type were summed up for all unit processes. 
Table S2 (in Supplementary Materials) displays the material and elements that formed the basis of the wind power plant's lifecycle analysis for a 25-year period of use. The total weight of the its materials and elements came to approximately two tons, $76 \%$ of which belonged to concrete. Besides concrete, the most important materials used in the wind power plant's lifecycle are steel (approx. 19\%), cast iron (approx $3 \%$ ), polymer materials (approx. $1 \%$ ) as well as aluminum, copper, and oils (in total approx. $1 \%$ ). It was assumed that in a 25 -year period of use there will be two replacements of the main gearbox [78] and an oil change every 5 years in both the hydraulic system and the main gearbox, with a total weight of $2560 \mathrm{~kg}$.

Table 2 lists the materials and elements of the nacelle and rotor that are subject to replacement after 25 years of use for the scenario in which a 50-year lifecycle was assumed along with the modernization of the test object, while Table 2 lists the weight of the materials replaced. Approximately $48 \%$ of the materials and components of the nacelle and over $53 \%$ of the materials and components of the rotor undergo replacement. The following elements are replaced with completely ones: the generator and its accompanying cooler, the gearbox, cooler, hydraulic system, and blades (Table 2). This constitutes a small percentage of the total mass of the power plant undergoing modernization. The components in the nacelle that are replaced constitute less than $2 \%$ of the total mass, while the rotor components account for slightly over $1 \%$ (Table 2 ). Most of the materials listed are polymeric materials $(1.15 \%)$, which are replaced in their entirety (Table 3$)$. The material with the second highest share in replacement is cast iron $(1.02 \%)$, and the third is steel $(0.60 \%)$.

\subsubsection{Determining the Efficiency Indicator from Environmental and Energy Costs}

Efficiency of environmental costs is understood as the relation between environmental benefits in the lifecycle and the environmental costs incurred in the form of: the total impact of one thousand Europeans in the course of one year (efficiency of environmental costs), greenhouse gas emissions (environmental efficiency of $\mathrm{CO}_{2}$ emissions), emissions of substances causing acidification (environmental efficiency of $\mathrm{SO}_{2}$ emissions), and emissions of substances causing eutrophication (environmental efficiency of $\mathrm{PO}_{4}$ emissions).

Energy efficiency is understood as the relation between energy benefits in the lifecycle and the energy costs incurred.

To analyze the efficiency of the wind power plant in a 25-year period of use, dependency (7), expanding upon formula (1), was used

$$
E\left(t_{L C 1}\right)=\frac{U\left(t_{L C 1}\right)}{N\left(t_{L C 1}\right)}=\frac{\sum_{i=1}^{t} U_{i}}{N_{W}^{1}+\sum_{i=1}^{t} N_{i}+N_{Z}^{1}}=\frac{U_{r} \cdot t_{L C 1}}{N_{W}^{1}+N_{r} \cdot t_{L C 1}+N_{Z}^{1}}
$$

where: $E\left(t_{L C 1}\right)$ - the integrated efficiency indicator during $t$ years of use, $U_{i}$ - benefits during the $i$-nth year of use, $N_{W}^{1}$ - costs at the production stage of the 25-year lifecycle, $N_{i}$ - costs in the $i$-nth year of use $N_{Z}^{1}$ - costs during post-use management during the 25-year lifecycle, $t_{L C 1}$ - time of use, $U_{r}$ - average annual benefits, $N_{r}$ - average annual use-related costs.

For a wind power plant that has been modernized during a 50-year period of use, the efficiency indicator is determined by a system of equations

$$
\left\{\begin{array}{l}
E(t)=\frac{U_{r} \cdot t}{N_{W}^{1}+N_{r} \cdot t+N_{Z}^{1}} \quad \text { dla } \quad 0 \leq t \leq 25 \\
E(t)=\frac{U_{r} \cdot t}{\left(N_{W}^{1}+N_{W}^{2}\right)+N_{r} \cdot t+\left(N_{Z}^{1}+N_{Z}^{2}\right)} \quad \text { dla } \quad 25<t \leq 50
\end{array}\right.
$$

where: $N_{W}^{2}$ - costs at the stage of producing new elements used in the modernization process, $N_{Z}^{2}-$ costs at the stage of post-use management of the replaced elements of the wind power plant. 
Table 2. List of the materials and elements replaced during wind power plant modernization.

\begin{tabular}{|c|c|c|c|c|c|c|}
\hline Lp. & Element & Material & Mass [kg] & $\begin{array}{l}\text { Share in } \\
\text { component, \% }\end{array}$ & $\begin{array}{l}\text { Share in } \\
\text { unit, } \%\end{array}$ & $\begin{array}{l}\text { Share in } \\
\text { WPP, \% }\end{array}$ \\
\hline 1 & \multicolumn{3}{|l|}{ Nacelle } & & & \\
\hline \multirow{4}{*}{1.1} & \multirow{4}{*}{$\begin{array}{l}\text { Generator with } \\
\text { the radiator }\end{array}$} & Copper & 1430 & 19.07 & 2.10 & 0.08 \\
\hline & & Cast iron & 3920 & 52.27 & 5.76 & 0.22 \\
\hline & & Steel & 2090 & 27.87 & 3.07 & 0.12 \\
\hline & & Replacement & 7440 & 99.20 & 10.94 & 0.42 \\
\hline \multirow{4}{*}{1.2} & \multirow{4}{*}{ Gearbox } & Upgraded steel & 2620 & 15.41 & 3.85 & 0.15 \\
\hline & & Cast iron & 14,060 & 82.71 & 20.68 & 0.80 \\
\hline & & Oil & 280 & 1.65 & 0.41 & 0.02 \\
\hline & & Replacement & 16,960 & 99.76 & 24.94 & 0.97 \\
\hline 1.3 & Radiators & Aluminum & 960 & 100.00 & 1.41 & 0.05 \\
\hline \multirow{5}{*}{1.4} & \multirow{5}{*}{$\begin{array}{l}\text { Hydraulic } \\
\text { system }\end{array}$} & Oil & 360 & 9.89 & 0.53 & 0.02 \\
\hline & & Steel & 2660 & 73.08 & 3.91 & 0.15 \\
\hline & & Aluminum & 420 & 11.54 & 0.62 & 0.02 \\
\hline & & Other & 200 & 5.49 & 0.29 & 0.01 \\
\hline & & Replacement & 3640 & 100.00 & 5.35 & 0.21 \\
\hline \multirow{4}{*}{1.5} & \multirow{4}{*}{$\begin{array}{l}\text { Switchgears, } \\
\text { inverters, } \\
\text { connections }\end{array}$} & Steel & 340 & 38.64 & 0.50 & 0.02 \\
\hline & & Copper & 240 & 27.27 & 0.35 & 0.01 \\
\hline & & Aluminum & 180 & 20.45 & 0.26 & 0.01 \\
\hline & & Replacement & 760 & 86.36 & 1.12 & 0.04 \\
\hline \multirow{3}{*}{1.6} & \multirow{3}{*}{ Nacelle housing } & Steel & 1100 & 6.00 & 1.62 & 0.06 \\
\hline & & Polymer materials & 1815 & 9.90 & 2.67 & 0.10 \\
\hline & & Replacement & 2915 & 15.89 & 4.29 & 0.17 \\
\hline \multicolumn{3}{|c|}{ Nacelle total } & 68,000 & & 100.00 & 3.87 \\
\hline \multicolumn{3}{|c|}{ Replacement } & 32,675 & & 48.05 & 1.86 \\
\hline 2 & \multicolumn{3}{|l|}{ ROTOR } & & & \\
\hline \multirow{3}{*}{2.1} & \multirow{3}{*}{ Blades } & Steel & 1750 & 8.75 & 4.61 & 0.10 \\
\hline & & $\begin{array}{l}\text { Polymer materials } \\
\text { reinforced with } \\
\text { carbon fiber and } \\
\text { glass fiber }\end{array}$ & 18,250 & 91.25 & 48.03 & 1.04 \\
\hline & & Replacement & 20,000 & 100.00 & 52.63 & 1.14 \\
\hline \multirow[b]{2}{*}{2.2} & \multirow[b]{2}{*}{ Hub } & Polymer materials & 200 & 1.11 & 0.53 & 0.01 \\
\hline & & Replacement & 200 & 1.11 & 0.53 & 0.01 \\
\hline \multicolumn{3}{|c|}{ Rotor total } & 38,000 & & 100.00 & 2.16 \\
\hline \multicolumn{3}{|c|}{ Replacement } & 20,200 & & 53.16 & 1.15 \\
\hline
\end{tabular}

Table 3. Mass of materials replaced during wind power plant (WPP) modernization.

\begin{tabular}{|c|c|c|c|c|c|c|c|c|c|c|}
\hline & $\begin{array}{l}\text { Mass } \\
{[\mathrm{kg}]}\end{array}$ & $\begin{array}{l}\text { Share in } \\
\text { WPP [\%] }\end{array}$ & $\begin{array}{l}\text { Alum } \\
{[\mathrm{kg}]}\end{array}$ & $\begin{array}{l}\text { urKopper } \\
{[\mathrm{kg}]}\end{array}$ & $\begin{array}{l}\text { Steel } \\
{[\mathrm{kg}]}\end{array}$ & $\begin{array}{l}\text { c. Iron } \\
{[\mathrm{kg}]}\end{array}$ & $\begin{array}{l}\text { Polymer } \\
\text { Materials [kg] }\end{array}$ & $\begin{array}{l}\text { Concrete } \\
{[\mathrm{kg}]}\end{array}$ & $\begin{array}{l}\text { Oil } \\
{[\mathrm{kg}]}\end{array}$ & $\begin{array}{l}\text { Other } \\
{[\mathrm{kg}]}\end{array}$ \\
\hline WPP Total & $1,756,810$ & 100 & 3715 & 2050 & 336,300 & 52,015 & 20,265 & $1,339,615$ & 640 & 2210 \\
\hline Replacement & 52,875 & 3.01 & 1560 & 1670 & 10,560 & 17,980 & 20,265 & 0 & 640 & 200 \\
\hline \multicolumn{3}{|c|}{$\%$ share of total materials in WPP } & 0.21 & 0.12 & 19.14 & 2.96 & 1.15 & 76.25 & 0.04 & 0.13 \\
\hline \multicolumn{3}{|c|}{$\begin{array}{l}\% \text { share of replacement materials in } \\
\text { WPP }\end{array}$} & 0.09 & 0.10 & 0.60 & 1.02 & 1.15 & 0 & 0.04 & 0.01 \\
\hline
\end{tabular}

In accordance with dependencies (21) and (22), integrated efficiency indicators were determined:

- From environmental costs, where the result of a wind power plant's environmental impact (in environmental points) at certain stages of the lifecycle were assumed as costs;

- From greenhouse gas emissions, where quantitative emissions of $\mathrm{CO}_{2} \mathrm{eq}$ (in $\mathrm{kg}$ ) at certain stages of the wind power plant's lifecycle are assumed as costs, this being obtained as the result of completing LCA analysis; 
- From the emissions of substances causing acidification, where quantitative emissions of $\mathrm{SO}_{2} \mathrm{eq}$ (in $\mathrm{kg}$ ) at certain stages of the wind power plant's lifecycle are assumed as costs, this being obtained as the result of completing LCA analysis;

- From the emissions of substances causing eutrophication, where quantitative emissions of $\mathrm{PO}_{4} \mathrm{eq}$ (in $\mathrm{kg}$ ) at certain stages of the wind power plant's lifecycle are assumed as costs, this being obtained as the result of completing LCA analysis;

- From energy costs, where potential energy demands (in MJ) at certain stages of the wind power plant's lifecycle are assumed as costs.

\subsubsection{Determining the Payback Time for Modernization}

For the wind power plant that has undergone modernization analyzed herein, the payback time for modernization (18) is defined by

$$
T_{M 1}=\frac{t_{L C 1}\left(N_{W}^{2}+N_{Z}^{2}\right)}{N_{W}^{1}+N_{Z}^{1}}
$$

Payback times for modernization were determined for ecological costs in the form of greenhouse gas emissions, substances causing acidification, substances causing eutrophication, and energy costs for the wind power plant in a 25-year and 50-year lifecycle.

\subsubsection{Determining the Sustainable Modernization Indicator}

For the wind power plant that has undergone modernization analyzed herein, the sustainable modernization indicator is defined by:

$$
E_{M 1}=\frac{E\left(t_{L C 2}\right)}{E\left(t_{L C 1}\right)}=\frac{E\left(t_{L C 2}=50\right)}{E\left(t_{L C 1}=25\right)}=\frac{\frac{50 U_{r}}{\left(N_{W}^{1}+N_{W}^{2}\right)+50 N_{r}+\left(N_{Z}^{1}+N_{Z}^{2}\right)}}{\frac{25 U_{r}}{N_{W}^{1}+25 N_{r}+N_{Z}^{1}}}=\frac{2\left(N_{W}^{1}+N_{Z}^{1}+25 N_{r}\right)}{\left(N_{W}^{1}+N_{W}^{2}+N_{Z}^{1}+N_{Z}^{2}+50 N_{r}\right)}
$$

The value of the of the sustainable modernization indicator was determined for the efficiency of ecological costs, of greenhouse gas emissions, of substances causing acidification, of substances causing eutrophication, and of energy costs for the wind power plant in a 25-year and 50-year lifecycle.

The two dependencies above (23), (24) make it possible to assess the modernization process. They may be applied to assess other machines and devices than the one analyzed in this paper.

\section{Results and Discussion}

\subsection{Costs in the Lifecycle of a Wind Power Plant in a 25-year Lifecycle and in One Subjected to Modernization}

Table 4 presents the results of LCA analysis with the use of Eco-indicator 99 modelling (total value of the eco-indicator, acidification, eutrophication) and IPCC modelling (greenhouse gas emissions) at particular stages of the wind power plant's lifecycle, which are the ecological costs in the model of the integrated ecological efficiency indicator. 
Table 4. Ecological costs determined with the aid of the LCA method in the material stages of a 25 years and 50-year lifecycle of a wind power plant (the Eco-indicator 99 method).

\begin{tabular}{|c|c|c|c|c|c|}
\hline Lifecycle Stage & & $\begin{array}{l}\text { Total Eco-Indicator } \\
\text { Value }[\mathrm{Pt}]\end{array}$ & $\begin{array}{l}\text { Emissions of } \\
\mathrm{CO}_{2} \mathrm{eq}[\mathrm{kg}]\end{array}$ & $\begin{array}{l}\text { Acidification } \\
{\left[\mathrm{kg} \mathrm{SO}_{2} \mathrm{eq}\right]}\end{array}$ & $\begin{array}{l}\text { Eutrophication } \\
{\left[\mathrm{kg} \mathrm{PO}_{4} \mathrm{eq}\right]}\end{array}$ \\
\hline \multirow{2}{*}{ Production } & $N_{W 25}$ & 322,460 & $2,700,559$ & 141,842 & 728 \\
\hline & $N_{W 50}$ & 401,663 & $3,381,947$ & 176,735 & 907 \\
\hline \multirow{2}{*}{ Use } & $N(t=25)$ & 20,955 & 589,300 & 3712 & 149 \\
\hline & $N(t=50)$ & 41,910 & $1,178,600$ & 7424 & 298 \\
\hline \multirow{2}{*}{$\begin{array}{l}\text { Post-use } \\
\text { management }\end{array}$} & $N_{Z 25}$ & $-13,423$ & $-528,712$ & -1203 & -67 \\
\hline & $N_{Z 50}$ & $-30,271$ & $-657,873$ & -1499 & -84 \\
\hline
\end{tabular}

In each of the lifecycle stages considered, higher environmental costs in the form of a negative impact on the ecosystem and human health were recorded for the 50-year lifecycle of a wind power plant. However, if the values under consideration were compared not to one 25-year lifecycle of a wind power plant, but to the sum of two lifecycles (with disassembly and recycling after 25 years or landfilling the installation plus the installation of a new one along with 25 years of operation), it is evident that the use of the power plant over a 50-year period with modernization being performed after 25 years of operation will result in lower values of the eco-indicator and greenhouse gas emissions by approx. $40-50 \%$ and lower emissions of substances causing acidification or eutrophication by approx. $40 \%$ (depending on the stage of the lifecycle) compared to the use of two wind power plants during this period. The highest costs in both scenarios occurred at the stage of production of wind power plant components, while the lowest were at the stage of post-use management, where the value of costs is generally reduced because of the possibility of recovering materials and energy from elements ending their lifecycles. In both cases throughout the entire lifecycle there were costs in the form $\mathrm{CO}_{2}$ emissions, while the lowest costs were in the form of emissions causing eutrophication.

Table 5 displays the results of energy consumption analysis at different lifecycle stages which constitute energy costs in the energy efficiency indicator model. In each of the lifecycle stages that were assessed, the greatest energy costs were recorded for the 50-year wind power plant lifecycle. However, again, if these values were compared not to one 25-year wind power plant lifecycle, but to the sum of two lifecycles, it is evident that the use of the wind power plant over a 50-year period results in a reduction of energy costs from approx. 30 to $50 \%$ (depending on the lifecycle stage), where most important thing is to reduce energy consumption at the production stage of wind power plant elements.

Table 5. Energy costs determined with the use of the LCA method in the material stages of a 25 years and 50 years wind power plant lifecycle (cumulative energy demand (CED) method).

\begin{tabular}{lll}
\hline Lifecycle Stage & & Energy Consumption [MJ] \\
\hline \multirow{2}{*}{ Production } & $N_{W 25}$ & $41,559,527$ \\
& $N_{W 50}$ & $52,740,112$ \\
Use & $N(t=25)$ & $7,661,400$ \\
\multirow{2}{*}{ Post-use management } & $N(t=50)$ & $15,322,800$ \\
& $N_{Z 25}$ & $-5,779,943$ \\
& $N_{Z 50}$ & $-8,014,646$ \\
\hline
\end{tabular}

\subsection{Efficieny Indicators from Ecological Costs and Energy Costs and Payback Time for Modernization}

The specified benefits and costs, after substituting them into dependencies (21) and (22), made it possible to determine the values of the integrated ecological efficiency indicator from ecological costs, from greenhouse gas emissions, from emissions of substances causing acidification, from emissions of substances causing eutrophication. It was also possible to determine the values of the integrated energy efficiency indicator. 
In the case of a modernized wind power plant, for every 1 Pt of environmental impact approximately $2.32 \mathrm{GJ}$ of electricity is produced, for every $1 \mathrm{t}$ of $\mathrm{CO}_{2}$ eq emissions-246 GJ of electricity, for every $1 \mathrm{t}$ of $\mathrm{SO}_{2}$ eq emissions - $5247 \mathrm{GJ}$ of electricity, for every $1 \mathrm{t}$ of PO4eq emissions-854,766 GJ of electricity. The energy benefits of a wind power plant after modernization are almost 16 times higher than the costs incurred. What is noticeable is that, in the case of a modernized wind power plant, the values of the efficiency indicator from ecological costs and energy costs increase from 1.4 to 1.6 times in relation to the wind power plant with a 25-year lifecycle (Figures 4-8). These values reflect the better use of costs in the wind power plant's lifecycle to produce benefits when the wind power plant is modernized and its lifecycle is extended by another 25 years.

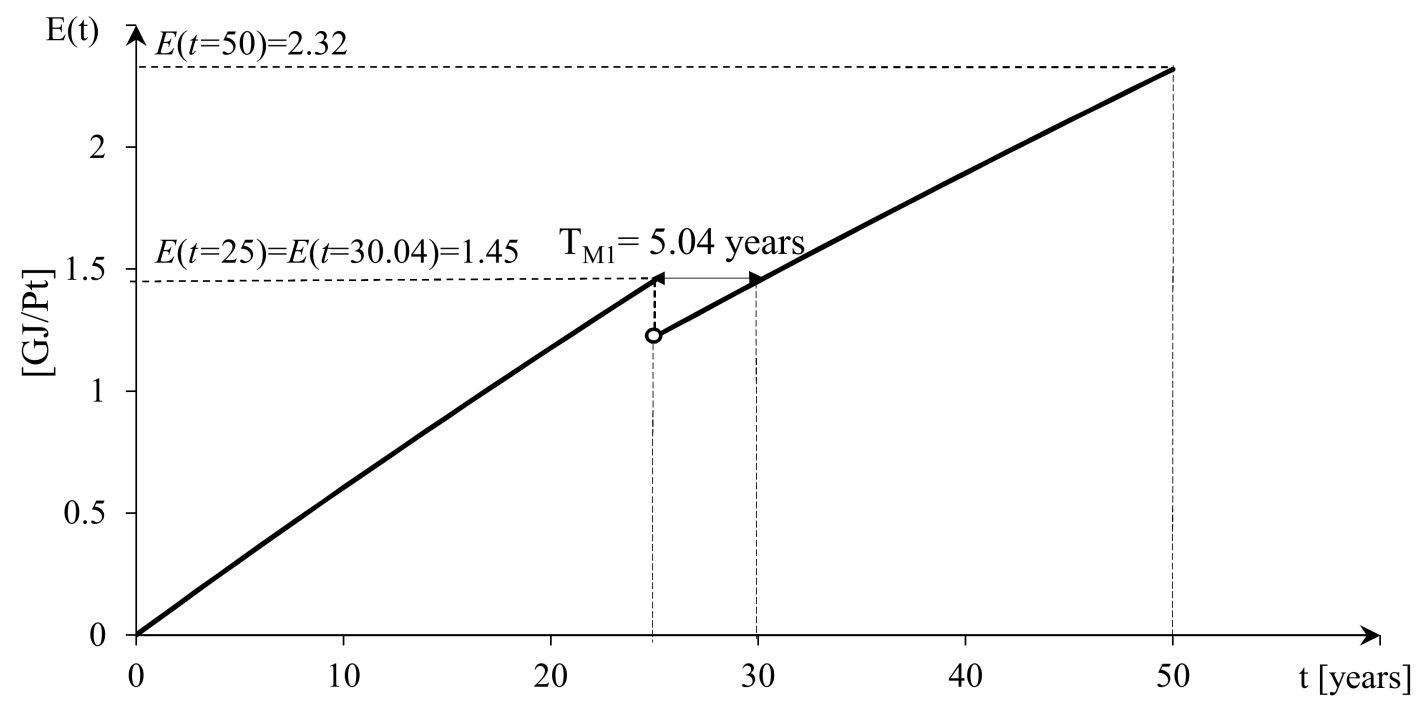

Figure 4. A graphical interpretation of the integrated efficiency indicator from ecological costs for a wind power plant undergoing modernization during a 50-year period of use.

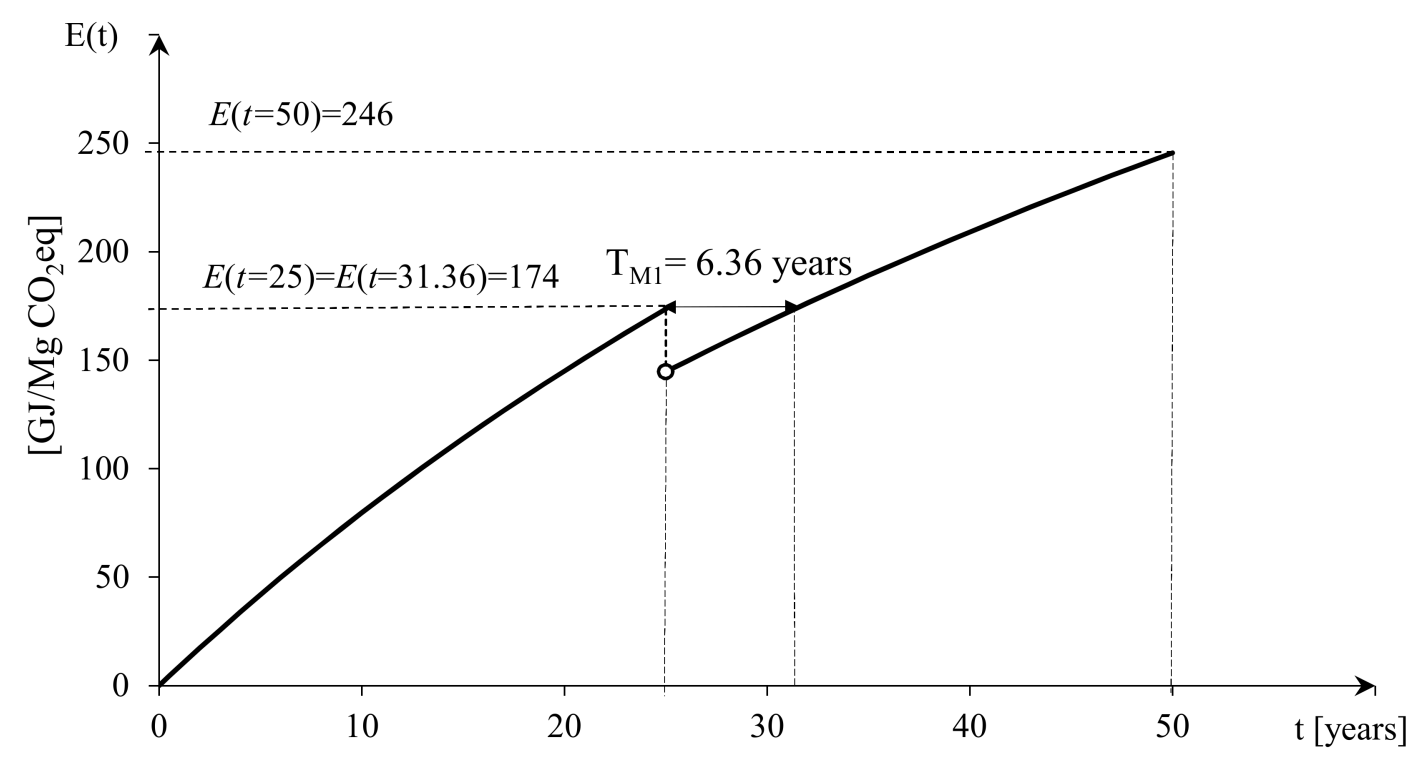

Figure 5. A graphical interpretation of the integrated ecological efficiency indicator from $\mathrm{CO}_{2}$ emissions for a wind power plant undergoing modernization during a 50-year period of use. 


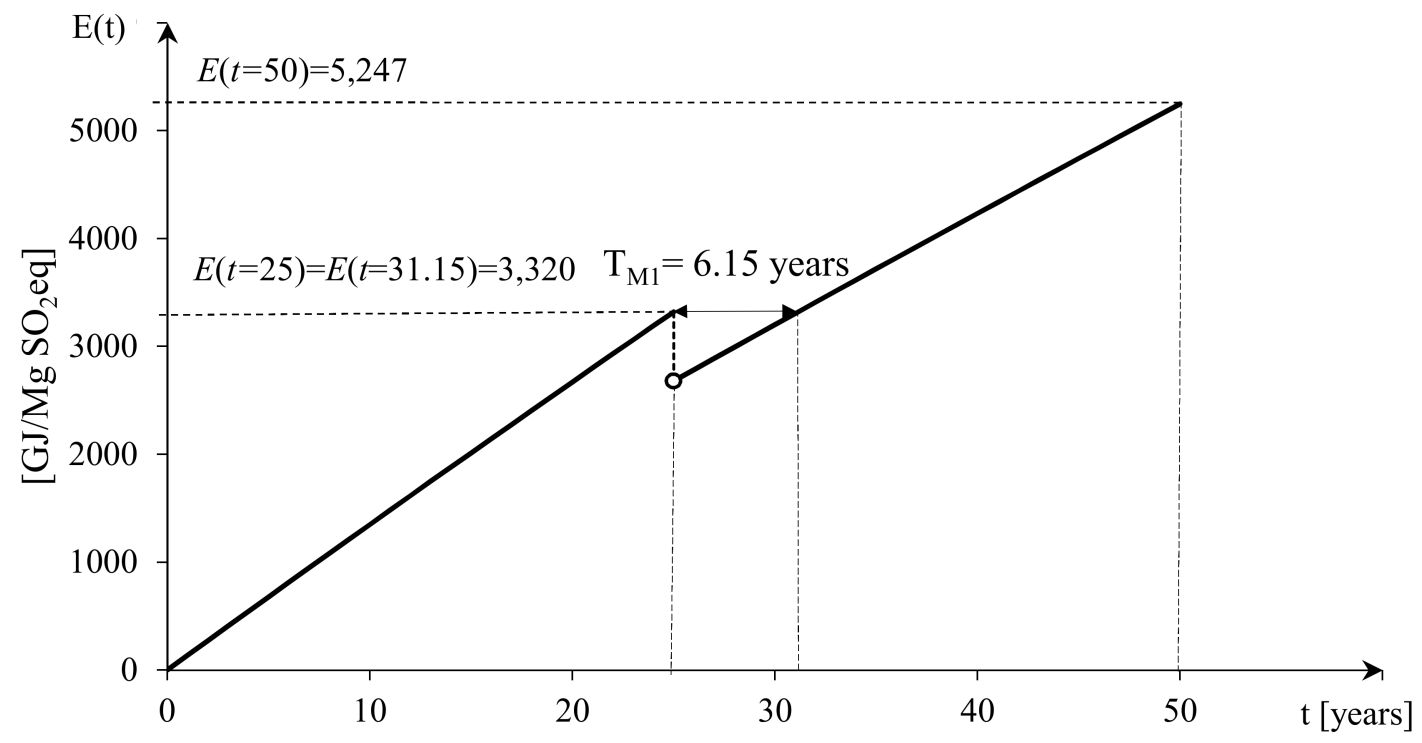

Figure 6. A graphical interpretation of the integrated ecological efficiency indicator from $\mathrm{SO}_{2}$ emissions for a wind power plant undergoing modernization during a 50-year period of use.

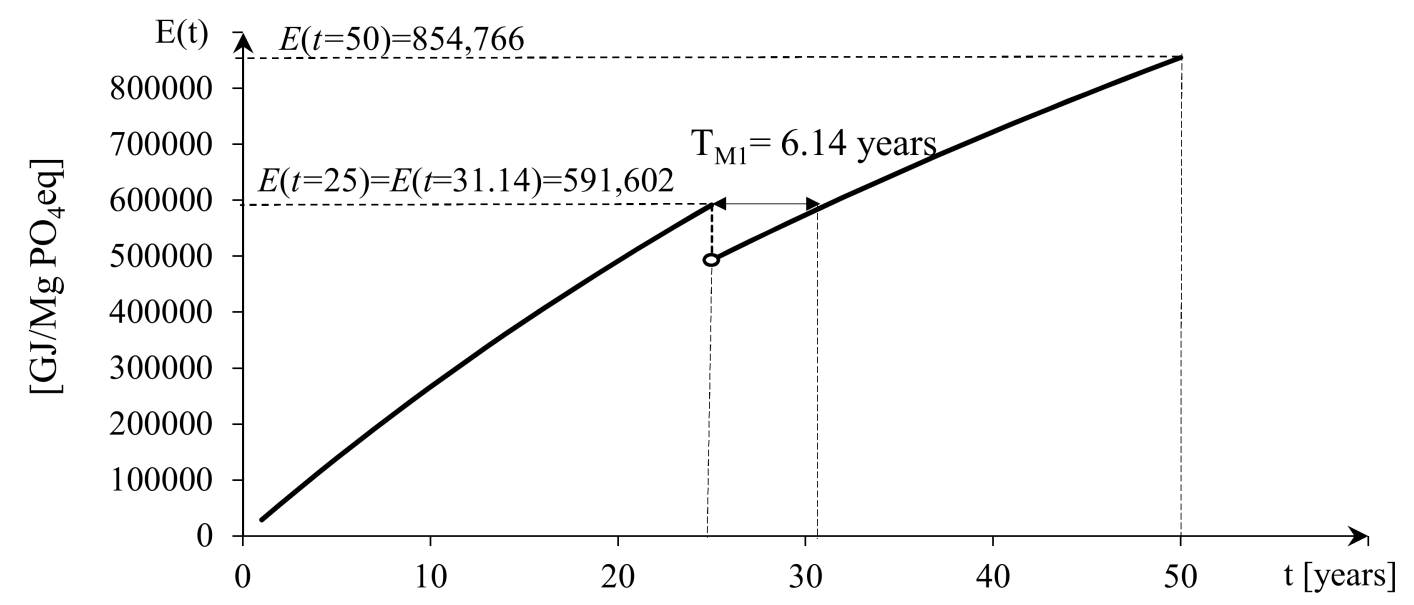

Figure 7. A graphical interpretation of the integrated ecological efficiency indicator from $\mathrm{PO}_{4}$ emissions for a wind power plant undergoing modernization during a 50-year period of use.

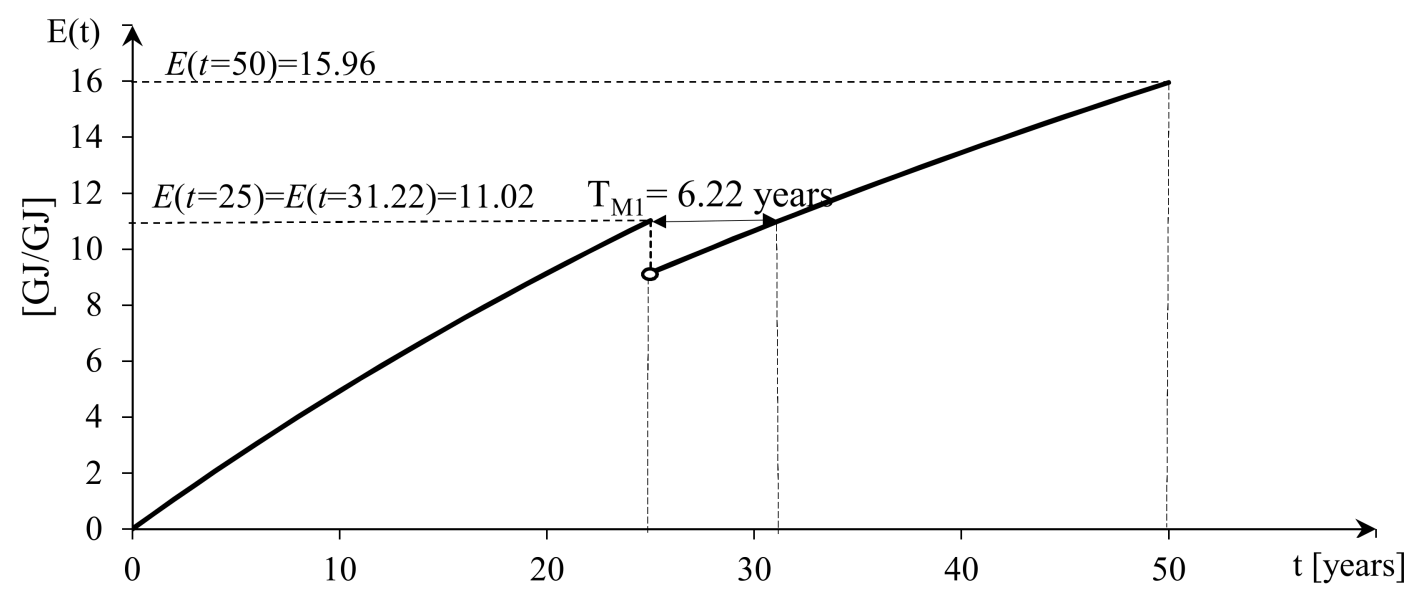

Figure 8. A graphical interpretation of the integrated efficiency indicator from energy costs for a wind power plant undergoing modernization during a 50-year period of use. 
Figures 4-8 present a graphical interpretation of the efficiency indicator for a wind power plant undergoing modernization during a 50-year period of use.

Figure 4 presents the dependence of the integrated efficiency from ecological costs for a 50-year period of use with modernization performed after 25 years. For the integrated efficiency from ecological costs, energy production at the use-stage was defined as a benefit, and environmental points resulting from LCA analysis were used as costs. Figure 4 shows that the payback time for environmental costs incurred for wind power plant modernization is 5.04 years, and the integrated ecological efficiency after 50 years of use is higher than after 25 years. Unfortunately, at the time WPP elements are replaced, there is an increase in costs, resulting in a decrease in efficiency below the level for the WPP operating for 25 years.

Figure 5 presents the dependence of the integrated efficiency from $\mathrm{CO}_{2}$ emissions for a 50-year period of use with modernization performer after 25 years. For the integrated efficiency from the emissions of $\mathrm{CO}_{2}$ equivalent, energy production at the use-stage was defined as a benefit, and the emissions of $\mathrm{CO}_{2}$ equivalent resulting from LCA analysis were used as costs. Figure 5 shows that the payback time for costs in the form $\mathrm{CO}_{2}$ emissions incurred for wind power plant modernization is 6.36 years, and the integrated efficiency from $\mathrm{CO}_{2}$ emissions after 50 years of use is higher than after 25 years. Unfortunately, at the time WPP elements are replaced, there is an increase in costs, resulting in a decrease in efficiency below the level for the WPP operating for 25 years. In this case, payback with regard to $\mathrm{CO}_{2}$ emissions occurs more slowly than in the case of total ecological costs. This is primarily the result of a significant increase in costs in the form of $\mathrm{CO}_{2}$ emissions during the production and use-stage (Table 4).

In the case of integrated efficiency from the emissions of substances causing acidification $\left(\mathrm{SO}_{2}\right)$, energy production at the use-stage was defined as a benefit (Figure 6). Costs were constituted by the total emissions of $\mathrm{SO}_{2}$ equivalent at individual stages of the WPP lifecycle. As in the case of the integrated efficiency indicator from $\mathrm{CO}_{2}$ emissions, the payback time for modernization was more than 6 years, which may be affected primarily by the increase in the emissions of substances causing acidification $\left(\mathrm{SO}_{2} \mathrm{eq}\right)$ at the production stage (Table 4). Figure 6 shows that the integrated efficiency from $\mathrm{SO}_{2}$ emissions after 50 years of use is higher than after 25 years.

In accordance with Figure 7, the integrated efficiency indicator from the emissions of substances causing eutrophication $\left(\mathrm{PO}_{4}\right)$ is higher after 50 years of use than after 25 . The WPP returns to pre-modernization efficiency after 6.14 years, which is a value close to the payback time from the emissions of substances causing acidification $\left(\mathrm{SO}_{2}\right)$. The payback time is mainly affected by the increase in costs in the form of $\mathrm{PO}_{4}$ emissions at the stage at which the replaced WPP elements are produced and by the emissions generated at the use-stage which are connected to maintenance, to oil changes in particular.

In the case of the integrated efficiency from energy costs, energy production at the use-stage was again defined as a benefit (Figure 8). Costs were constituted by total energy consumption at particular stages of the WPP lifecycle. In this impact area, the payback time for modernization was more than 6 years, which is tied primarily to the increase in energy costs necessary to produce the replaced elements and to the energy consumption at the use-stage relating to the energy consumption for maintenance and for the power plant's own needs.

Values of payback time for modernization were determined on the basis of dependence (23). The wind power plant, after modernization, returns to the efficiency it achieved in the last year before modernization after about 6 years, depending on the efficiency area which is being considered (Figures 4-8). The quickest return to pre-modernization efficiency is in the case of environmental efficiency from ecological costs (approx. 5 years) and the longest such return is in the case of efficiency from greenhouse gas emissions (over 6 years) (Figures 4-8).

By modernizing a wind power plant, one achieves an extension, its time of use, as well as an increase in benefits from its functioning in the form of electricity production. Owing to modernization, there was an increase both in the integrated ecological efficiency indicator and in the integrated energy 
efficiency indicator throughout the wind power plant's lifecycle, despite the fact that, during the years directly proceeding modernization, there was a drop in these values. Every subsequent modernization and replacement of elements will cause a temporary drop in the integrated efficiency indicator, which is related to an increase in ecological costs and energy costs the moment new elements are added.

The modernization considered in this paper included the replacement of the nacelle, rotor, and blades with new ones of the same power. A constant average annual productivity was assumed, one which was the same for the 25-year and 50-year cycles. Replacing the elements with one of greater power would cause a change both in benefits (such as an increase in annual average productivity) and in costs. Costs would potentially be higher than in the case of a rotor of the same power because of an increase in the mass of the elements, and, as previous research has shown [10], the environmental impact of materials used to produce wind power plants is strongly related to their mass (greater mass $=$ higher eco-indicator values). However, considering technological advances and developments in the construction of wind power plants, it is difficult to predict how, over the next 25 years, constructions, production methods, and the materials used to produce such objects will change, which means it is not possible to clearly determine how ecological costs and energy costs will change, the same being true for the values of the integrated efficiency indicators from ecological costs and energy costs.

Of crucial importance is the fact that, as a result of extending the lifecycle of a wind power plant, the use of natural resources is thereby limited, as is the energy used to produce its components, and, not least of all, the post-use management of a part of its elements is postponed.

\subsection{Sustainable Modernization Indicators}

Table 6 presents the values of the sustainable modernization indicator in relation to environmental costs and energy costs for wind power plant modernization. Values were determined on the basis of dependence (24). The higher the value of the sustainable modernization indicator, the greater was the increase in the efficiency of the wind power plant because of modernization. The highest value of the sustainable modernization indicator was obtained with respect to the wind power plant's ecological efficiency from ecological costs, and the lowest with respect to the efficiency indicator from the emissions of substances causing eutrophication (Table 6). In the case of all the areas under consideration, an increase was recorded in the efficiency of the use of costs by about 1.44-1.6 times, which is primarily the result of an increase in benefits (total electricity production) over a 50-year lifecycle.

Table 6. Values of the sustainable modernization indicator.

\begin{tabular}{ll}
\hline The Sustainable Modernization Indicator $E_{M 1}[-]$ & \\
\hline from ecological costs & 1.596 \\
from greenhouse gas emissions $\left(\mathrm{CO}_{2} \mathrm{eq}\right)$ & 1.415 \\
from emissions of substances causing acidification $\left(\mathrm{SO}_{2} \mathrm{eq}\right)$ & 1.58 \\
from emissions of substances causing eutrophication $\left(\mathrm{PO}_{4} \mathrm{eq}\right)$ & 1.444 \\
from energy costs & 1.448 \\
\hline
\end{tabular}

\section{Summary and Conclusions}

The aim of the paper was achieved by developing a methodology to assess devices subjected to sustainable modernization, i.e., restoration of an object such that it has the properties of a new device. An assessment of the ecological efficiency and energy efficiency of a modernized wind power plant was carried out with the use of an integrated efficiency indicator. Two indicators were proposed to assess modernization efficiency: the payback time of costs for modernization (23) and the sustainable modernization indicator (24).

In the case of the wind power plant analyzed herein, the payback time for costs incurred for modernization (23) came to 6.36 years from greenhouse gas emissions, 6.22 years from energy costs, and, from the remaining costs analyzed, from 5.04 years to 6.15 years. 
In the case of the wind power plant analyzed herein, the sustainable modernization indicator from greenhouse gas emissions came to 1.42, and from energy costs-1.45 (Table 6). This means an over $40 \%$ increase in the ecological efficiency of the use of energy costs from greenhouse gases and in the ecological efficiency of the use of energy costs after the completion of the lifecycle of the wind power plant subjected to sustainable modernization.

Analysis of the ecological costs throughout the lifecycle of a modernized wind power plant showed that higher environmental costs in the form of negative impacts on the ecosystem and on human health were recorded in the case of the 50-year lifecycle of a wind power plant. If the values under consideration were compared not to one 25-year lifecycle of a wind power plant, but to the sum of two lifecycles (with disassembly and recycling after 25 years or landfilling the installation plus the installation of a new one along with 25 years of operation), it is evident that the use of the power plant over a 50-year period with modernization being performed after 25 years of operation will result in lower values of the eco-indicator and greenhouse gas emissions by approx. $40-50 \%$ and lower emissions of substances causing acidification or eutrophication by approx. $40 \%$ (depending on the stage of the lifecycle) compared to the use of two wind power plants during this period.

The indicators of modernization assessment proposed herein fit into a higher assessment of the closed-loop economy, that is, an economic system in which the consumption of raw materials, energy, emissions, and waste volume is minimized by creating a closed process loop. Of crucial importance is the fact that, as a result of extending the lifecycle of a wind power plant, the use of natural resources is thereby limited, as is the energy used to produce its components, and, not least of all, the post-use management of a part of its elements is postponed.

Sustainable modernization also fits into a strategy of sustainable development where an increase in electricity production essential for development results in a reduction of ecological and energy costs per unit of energy produced.

The authors call for the creation of incentive programs via legal changes for wind power plant investors and producers which relate to the implementation of sustainable modernization that results in a reduction of the environmental burdens accompanying energy production.

The assessment methodology proposed herein as well as the models developed to assess the effects of modernization are universal and can be applied to other technical facilities as both the benefits and the costs can be expressed in various units adapter to the specific nature of any technical object's operation. The indicators presented herein constitute one of the elements to assess the effects of modernization and are a form of support for operators and those who manage the lifecycles of technical objects.

Supplementary Materials: The following are available online at http://www.mdpi.com/1996-1073/13/6/1461/s1. Table S1: Lifetime-extension methods and operations (the authors' own work based on [34]). Table S2: Materials and elements used to build a wind power plant.

Author Contributions: Conceptualization, R.K. and J.F.; methodology, R.K. and W.K.; software, P.B.-W. and R.K.; validation, P.B.-W., R.K., and A.T.; formal analysis, J.F. and A.T.; investigation, R.K., W.K., and P.B.-W.; resources, R.K.; data curation, R.K., P.B.-W., and W.K.; writing-original draft preparation, R.K and W.K.; writing-review and editing, R.K., W.K., J.F., and A.T.; visualization, W.K. and P.B.-W.; supervision, R.K., J.F., A.T.; project administration, R.K. All authors have read and agreed to the published version of the manuscript.

Funding: This research received no external funding. The APC was paid by University of Science and Technology in Bydgoszcz

Conflicts of Interest: The authors declare no conflict of interest.

\section{References}

1. Haapala, K.R.; Prempreeda, P. Comparative life cycle assessment of 2.0 MW wind turbines. Int. J. Sustain. Manuf. 2014, 3, 170. [CrossRef]

2. Martínez, E.; Sanz, F.; Pellegrini, S.; Jiménez, E.; Blanco, J. Life cycle assessment of a multi-megawatt wind turbine. Renew. Energy 2009, 34, 667-673. [CrossRef] 
3. Wang, S.; Wang, S. Impacts of wind energy on environment: A review. Renew. Sustain. Energy Rev. 2015, 49, 437-443. [CrossRef]

4. Saidur, R.; Rahim, N.A.; Islam, M.R.; Solangi, K.H. Environmental impact of wind energy. Renew. Sustain. Energy Rev. 2011, 15, 2423-2430. [CrossRef]

5. Jeffery, R.D.; Krogh, C.; Horner, B. Adverse health effects of industrial wind turbines. Can. Fam. Physician 2013, 59, 473-475.

6. Piasecka, I.; Tomporowski, A. Analysis of Environmental and Energetical Possibilitiesof Sustainable Development of Wind and Photovoltaic Power Plants. Probl. Ekorozw. Probl. Sustain. Dev. 2018, 13, 125-130.

7. Gibon, T.; Hertwich, E.G.; Arvesen, A.; Singh, B.; Verones, F. Health benefits, ecological threats of low-carbon electricity. Environ. Res. Lett. 2017, 12, 034023. [CrossRef]

8. $\quad$ Basosi, R.; Cellura, M.; Longo, S.; Parisi, M.L. Life Cycle Assessment of Energy Systems and Sustainable Energy Technologies: The Italian Experience; Springer: Berlin/Heidelberg, Germany, 2018.

9. Luderer, G.; Pehl, M.; Arvesen, A.; Gibon, T.; Bodirsky, B.L.; de Boer, H.S.; Fricko, O.; Hejazi, M.; Humpenöder, F.; Iyer, G.; et al. Environmental co-benefits and adverse side-effects of alternative power sector decarbonization strategies. Nat. Commun. 2019, 10, 1-13. [CrossRef]

10. Ozoemena, M.; Cheung, W.M.; Hasan, R. Comparative LCA of technology improvement opportunities for a 1.5-MW wind turbine in the context of an onshore wind farm. Clean Technol. Environ. Policy 2018, 20, 173-190. [CrossRef]

11. Bonou, A.; Laurent, A.; Olsen, S.I. Life cycle assessment of onshore and offshore wind energy-from theory to application. Appl. Energy 2016, 180, 327-337. [CrossRef]

12. Mroziński, A.; Piasecka, I. Selected aspects of building, operation and environmental impact of offshore wind power electric plants. Pol. Marit. Res. 2015, 22, 86-92. [CrossRef]

13. Liu, P.; Barlow, C.Y. The environmental impact of wind turbine blades. IOP Conf. Ser. Mater. Sci. Eng. 2016, 139, 012032. [CrossRef]

14. Flizikowski, J.; Piasecka, I.; Kruszelnicka, W.; Tomporowski, A.; Mroziński, A. Destruction assessment of wind power plastics blade. Polimery 2018, 63, 5. [CrossRef]

15. Tomporowski, A.; Piasecka, I.; Flizikowski, J.; Kasner, R.; Kruszelnicka, W.; Mroziński, A.; Bieliński, K. Comparison Analysis of Blade Life Cycles of Land-Based and Offshore Wind Power Plants. Pol. Marit. Res. 2018, 25, 225-233. [CrossRef]

16. Tsai, L.; Kelly, J.C.; Simon, B.S.; Chalat, R.M.; Keoleian, G.A. Life Cycle Assessment of Offshore Wind Farm Siting: Effects of Locational Factors, Lake Depth, and Distance from Shore. J. Ind. Ecol. 2016, 20, 1370-1383. [CrossRef]

17. Stavridou, N.; Koltsakis, E.; Baniotopoulos, C.C. A comparative life-cycle analysis of tall onshore steel wind-turbine towers. Clean Energy 2019, zkz028, 1-10. [CrossRef]

18. Tomporowski, A.; Flizikowski, J.; Kruszelnicka, W.; Piasecka, I.; Kasner, R.; Mroziński, A.; Kovalyshyn, S. Destructiveness of Profits and Outlays Associated with Operation of Offshore Wind Electric Power Plant. Part 1: Identification of a Model and its Components. Pol. Marit. Res. 2018, 25, 132-139. [CrossRef]

19. Kasner, R. Ocena Korzyści i Nakładów Cyklu Życia Elektrowni Wiatrowej; Rozprawa doktorska, Poznań University of Technology: Poznań, Poland, 2016.

20. Piasecka, I.; Tomporowski, A.; Flizikowski, J.; Kruszelnicka, W.; Kasner, R.; Mroziński, A. Life Cycle Analysis of Ecological Impacts of an Offshore and a Land-Based Wind Power Plant. Appl. Sci. 2019, 9, 231. [CrossRef]

21. Tomporowski, A.; Flizikowski, J.; Kasner, R.; Kruszelnicka, W. Environmental Control of Wind Power Technology. Rocz. Ochr. Środowiska 2017, 19, 694-714.

22. Arabian-Hoseynabadi, H.; Oraee,H.; Tavner, P.J. Wind turbine productivity considering electrical subassembly reliability. Renew. Energy 2010, 35, 190-197. [CrossRef]

23. Mostafaeipour, A. Productivity and development issues of global wind turbine industry. Renew. Sustain. Energy Rev. 2010, 14, 1048-1058. [CrossRef]

24. Olatayo, K.I.; Wichers, J.H.; Stoker, P.W. Energy and economic performance of small wind energy systems under different climatic conditions of South Africa. Renew. Sustain. Energy Rev. 2018, 98, 376-392. [CrossRef]

25. Aghbashlo, M.; Tabatabaei, M.; Hosseini, S.S.B.; Dashti, B.; Mojarab Soufiyan, M. Performance assessment of a wind power plant using standard exergy and extended exergy accounting (EEA) approaches. J. Clean. Prod. 2018, 171, 127-136. [CrossRef] 
26. Sağlam, Ü. Assessment of the productive efficiency of large wind farms in the United States: An application of two-stage data envelopment analysis. Energy Convers. Manag. 2017, 153, 188-214. [CrossRef]

27. Dicorato, M.; Forte, G.; Pisani, M.; Trovato, M. Guidelines for assessment of investment cost for offshore wind generation. Renew. Energy 2011, 36, 2043-2051. [CrossRef]

28. Laura, C.-S.; Vicente, D.-C. Life-cycle cost analysis of floating offshore wind farms. Renew. Energy 2014, 66, 41-48. [CrossRef]

29. Myhr, A.; Bjerkseter, C.; Ågotnes, A.; Nygaard, T.A. Levelised cost of energy for offshore floating wind turbines in a life cycle perspective. Renew. Energy 2014, 66, 714-728. [CrossRef]

30. Snyder, B.; Kaiser, M.J. Ecological and economic cost-benefit analysis of offshore wind energy. Renew. Energy 2009, 34, 1567-1578. [CrossRef]

31. Alsaleh, A.; Sattler, M. Comprehensive life cycle assessment of large wind turbines in the US. Clean Technol. Environ. Policy 2019, 21, 887-903. [CrossRef]

32. Garrett, P.; Rønde, K. Life cycle assessment of wind power: Comprehensive results from a state-of-the-art approach. Int. J. Life Cycle Assess. 2013, 18, 37-48. [CrossRef]

33. Abeliotis, K.; Pactiti, D. Assessment of the environmental impacts of a wind farm in central Greece during its life cycle. Int. J. Renew. Energy Res. 2014, 4, 580-585.

34. Kruszelnicka, W.; Bałdowska-Witos, P.; Kasner, R.; Flizikowski, J.; Tomporowski, A.; Rudnicki, J. Evaluation of emissivity and environmental safety of biomass grinders drive. Przemyst Chem. 2019, 98, 1494-1498.

35. Jachimowski, R.; Szczepanski, E.; Klodawski, M.; Markowska, K.; Dabrowski, J. Selection of a Container Storage Strategy at the Rail-road Intermodal Terminal as a Function of Minimization of the Energy Expenditure of Transshipment Devices and CO2 Emissions. Rocz. Ochr. Sr. 2018, 20, 965-988.

36. Zajac, G.; Wegrzyn, A. Analysis of work parameters changes of diesel engine powered with diesel fuel and faee blends. Eksploat. I Niezawodn. Maint. Reliab. 2008, 17-24.

37. Caban, J.; Drozdziel, P.; Vrabel, J.; Sarkan, B.; Marczuk, A.; Krzywonos, L.; Rybicka, I. The Research on Ageing of Glycol-Based Brake Fluids of Vehicles in Operation. Adv. Sci. Technol. Res. J. 2016, 10, 9-16. [CrossRef]

38. Winiarski, G.; Gontarz, A.; Pater, Z. A new process for the forming of a triangular flange in hollow shafts from Ti6Al4V alloy. Arch. Civ. Mech. Eng. 2015, 15, 911-916. [CrossRef]

39. Wasiak, A.L. Effect of Biofuel Production on Sustainability of Agriculture. Procedia Eng. 2017, 182, 739-746. [CrossRef]

40. Flatland, K.; Hove, M.T.; Lavrutich, M.; Nagy, R.L.G. Irreversible Investment in Wind Turbines: Life-Extension Versus Repowering. Available online: http://realoptions.org/openconf2019/data/papers/394.pdf (accessed on 17 January 2020).

41. Ziegler, L.; Gonzalez, E.; Rubert, T.; Smolka, U.; Melero, J.J. Lifetime extension of onshore wind turbines: A review covering Germany, Spain, Denmark, and the UK. Renew. Sustain. Energy Rev. 2018, 82, 1261-1271. [CrossRef]

42. Piel, J.H.; Stetter, C.; Heumann, M.; Westbomke, M.; Breitner, M.H. Lifetime Extension, Repowering or Decommissioning? Decision Support for Operators of Ageing Wind Turbines. J. Phys. Conf. Ser. 2019, 1222, 012033. [CrossRef]

43. Siemens, A.G. (Ed.) Environmental Product Declaration. A Clean Energy Solution-from Cradle to Grave. Offshore Wind Power Plant Employing SWT-6.0-154; Siemens A.G. Wind Power: Hamburg, Germany, 2015.

44. Shafiee, M.; Brennan, F.; Espinosa, I.A. A parametric whole life cost model for offshore wind farms. Int. J. Life Cycle Assess. 2016, 21, 961-975. [CrossRef]

45. McCulloch, M.; Raynolds, M.; Laurie, M. Life-Cycle Value Assessment of a Wind Turbine; The Pembina Institute: Calgary, AB, Canada, 2000.

46. Jensen, J.P. Routes for Extending the Lifetime of Wind Turbines. Available online: https://www. plateconference.org/routes-extending-lifetime-wind-turbines/ (accessed on 19 December 2018).

47. Sun, H.; Gao, X.; Yang, H. Investigation into offshore wind farm repowering optimization in Hong Kong. Int. J. Low Carbon Technol. 2019, 14, 302-311. [CrossRef]

48. Lacal-Arántegui, R.; Uihlein, A.; Yusta, J.M. Technology effects in repowering wind turbines. Wind Energy 2020, 23, 660-675. [CrossRef]

49. Amiri, A.K.; Kazacoks, R.; McMillan, D.; Feuchtwang, J.; Leithead, W. Farm-wide assessment of wind turbine lifetime extension using detailed tower model and actual operational history. J. Phys. Conf. Ser. 2019, 1222, 012034. [CrossRef] 
50. Martínez, E.; Latorre-Biel, J.I.; Jiménez, E.; Sanz, F.; Blanco, J. Life cycle assessment of a wind farm repowering process. Renew. Sustain. Energy Rev. 2018, 93, 260-271. [CrossRef]

51. Flizikowski, J.; Tomporowski, A.; Kasner, R.; Mroziński, A.; Kruszelnicka, W. Machinery Life Cycle Efficiency Models for their Sustainable Development. Syst. Saf. Hum. Technol. Facil. Environ. 2019, 1, 363-370. [CrossRef]

52. Wasiak, A. Technologies of Biofuel Production. In Modeling Energetic Efficiency of Biofuels Production; Springer: Berlin/Heidelberg, Germany, 2019.

53. Wasiak, A.; Orynycz, O. The Effects of Energy Contributions into Subsidiary Processes on Energetic Efficiency of Biomass Plantation Supplying Biofuel Production System. Agric. Agric. Sci. Procedia 2015, 7, 292-300. [CrossRef]

54. Garrett, P.; Rønde, K. Life Cycle Assessment of Elektricity Production from V90-2.0MW Gridstreamer Wind Plant; Vestas Wind Systems A/S: Randers, Danmark, 2011.

55. Ding, Y. Data Science for Wind Energy; CRC Press: Boca Raton, FL, USA, 2019.

56. Byon, E.; Ntaimo, L.; Singh, C.; Ding, Y. Wind energy facility reliability and maintenance. In Handbook of Wind Power Systems; Springer: Berlin/Heidelberg, Germany, 2013.

57. Guezuraga, B.; Zauner, R.; Pölz, W. Life cycle assessment of two different 2 MW class wind turbines. Renew. Energy 2012, 37, 37-44. [CrossRef]

58. Razdan, P.; Garrett, P. Life Cycle Assessment of Electricity Production from an Onshore V136-4.2 MW Wind Plant. Available online: http://communityrenewables.org.au/wp-content/uploads/2013/02/Vestas-LifecycleAnalysis_2006.pdf (accessed on 4 March 2020).

59. Vestas Wind Systems A/S. Life Cycle Assessment of Offshore and Onshore Sited Wind Power Plants Based on Vestas V90-3.0 MW Turbines; Vestas Wind Systems A/S: Randers, Denmark, 2006.

60. Fox, T.R. Recycling Wind Turbine Blade Composite Material as Aggregate in Concrete. Available online: https://www.semanticscholar.org/paper/Recycling-wind-turbine-blade-composite-material-as-Fox/ 75a4ed7264c6680b3c0cf80201019d3b0e202c82 (accessed on 10 March 2020).

61. Karavida, S.; Nõmmik, R. Waste Management of End-of-Service Wind Turbines; Aalborg University: Aalborg, Denmark, 2015.

62. Goodship, V. Management, Recycling and Reuse of Waste Composites; Woodhead Publishing Limited: Cambridge, UK, 2010.

63. Rasul, M.G.; Azad, A.K.; Sharma, S.C. Clean Energy for Sustainable Development. Comparisons and Contrasts of New Approaches; Elsevier: Amsterdam, The Netherlands, 2017.

64. International Organization for Standardization ISO. ISO 14044:2006_Environmental Management-Life Cycle Assessment-Requirements and Guidelines 2006. Available online: https://www.iso.org/obp/ui/\#iso: std:iso:14044:en (accessed on 12 December 2019).

65. Dreyer, L.C.; Niemann, A.L.; Hauschild, M.Z. Comparison of Three Different LCIA Methods: EDIP97, CML2001 and Eco-indicator 99. Int. J. Life Cycle Assess. 2003, 8, 191-200. [CrossRef]

66. Alemam, A.; Cheng, X.; Li, S. Treating design uncertainty in the application of Eco-indicator 99 with Monte Carlo simulation and fuzzy intervals. Int. J. Sustain. Eng. 2018, 11, 110-121. [CrossRef]

67. Piasecka, I.; Tomporowski, A.; Piotrowska, K. Environmental analysis of post-use management of car tires. Przem. Chem. 2018, 97, 1649-1653.

68. Mannheim, V.; Fehér, Z.S.; Siménfalvi, Z. Innovative solutions for the building industry to improve sustainability performance with Life Cycle Assessment modelling. In Solutions for Sustainable Development; Taylor \& Francis Group: Milton Park, UK, 2019.

69. Mannheim, V.; Siménfalvi, Z. Determining a Priority Order between Thermic Utilization Processes for Organic Industrial Waste with LCA. Waste Manag. Environ. VI 2012, 163, 153-166.

70. Klos, Z. Ecobalancial assessment of chosen packaging processes in food industry. Int. J. Life Cycle Assess. 2002, 7, 309. [CrossRef]

71. Piotrowska, K.; Kruszelnicka, W.; Baldowska-Witos, P.; Kasner, R.; Rudnicki, J.; Tomporowski, A.; Flizikowski, J.; Opielak, M. Assessment of the Environmental Impact of a Car Tire throughout Its Lifecycle Using the LCA Method. Materials 2019, 12, 4177. [CrossRef] [PubMed]

72. Finnveden, G.; Hauschild, M.Z.; Ekvall, T.; Guinée, J.; Heijungs, R.; Hellweg, S.; Koehler, A.; Pennington, D.; Suh, S. Recent developments in Life Cycle Assessment. J. Environ. Manag. 2009, 91, 1-21. [CrossRef] [PubMed] 
73. Kirchain Jr, R.E.; Gregory, J.R.; Olivetti, E.A. Environmental life-cycle assessment. Nat. Mater. 2017, 16, 693-697. [CrossRef]

74. Puig, R.; Fullana-I-Palmer, P.; Baquero, G.; Riba, J.-R.; Bala, A. A cumulative energy demand indicator (CED), life cycle based, for industrial waste management decision making. Waste Manag. 2013, 33, 2789-2797. [CrossRef]

75. Röhrlich, M.; Mistry, M.; Martens, P.N.; Buntenbach, S.; Ruhrberg, M.; Dienhart, M.; Briem, S.; Quinkertz, R.; Alkan, Z.; Kugeler, K. A method to calculate the cumulative energy demand (CED) of lignite extraction. Int. J. Life Cycle Assess. 2000, 5, 369-373.

76. O'Brien, D.; Shalloo, L.; Patton, J.; Buckley, F.; Grainger, C.; Wallace, M. Evaluation of the effect of accounting method, IPCC v. LCA, on grass-based and confinement dairy systems' greenhouse gas emissions. Animal 2012, 6, 1512-1527. [CrossRef]

77. Roscoe, P. Method, Measurement, and Management in IPCC Climate Modeling. Hum. Ecol. 2016, 44, 655-664. [CrossRef]

78. Andersen, N.; Eriksson, O.; Hillman, K.; Wallhagen, M. Wind Turbines' End-of-Life: Quantification and Characterisation of Future Waste Materials on a National Level. Energies 2016, 9, 999. [CrossRef]

(C) 2020 by the authors. Licensee MDPI, Basel, Switzerland. This article is an open access article distributed under the terms and conditions of the Creative Commons Attribution (CC BY) license (http://creativecommons.org/licenses/by/4.0/). 